\title{
Plasticity and Multiplicity of Trophic Modes in the Dinoflagellate Karlodinium and Their Pertinence to Population Maintenance and Bloom Dynamics
}

\author{
Huijiao Yang $1,2,3$, Zhangxi Hu ${ }^{1,2,3, *(\mathbb{D})}$ and Ying Zhong Tang $1,2,3, *$ (D) \\ 1 CAS Key Laboratory of Marine Ecology and Environmental Sciences, Institute of Oceanology, \\ Chinese Academy of Sciences, Qingdao 266071, China; yanghuijiao@qdio.ac.cn (H.Y.) \\ 2 Laboratory for Marine Ecology and Environmental Science, Qingdao National Laboratory for Marine Science \\ and Technology, Qingdao 266237, China \\ 3 Centre for Ocean Mega-Science, Chinese Academy of Sciences, Qingdao 266071, China \\ * Correspondence: zhu@qdio.ac.cn (Z.H.); yingzhong.tang@qdio.ac.cn (Y.Z.T.); Tel.: +86-532-8289-6098
}

check for

updates

Citation: Yang, H.; Hu, Z.; Tang, Y.Z. Plasticity and Multiplicity of Trophic

\section{Modes in the Dinoflagellate}

Karlodinium and Their Pertinence to Population Maintenance and Bloom Dynamics. J. Mar. Sci. Eng. 2021, 9, 51.

https://doi.org/10.3390/jmse9010051

Received: 27 November 2020 Accepted: 28 December 2020

Published: 5 January 2021

Publisher's Note: MDPI stays neutral with regard to jurisdictional clai$\mathrm{ms}$ in published maps and institutional affiliations.

Copyright: (C) 2021 by the authors. Licensee MDPI, Basel, Switzerland. This article is an open access article distributed under the terms and conditions of the Creative Commons Attribution (CC BY) license (https:// creativecommons.org/licenses/by/ $4.0 /)$.

\begin{abstract}
As the number of mixotrophic protists has been increasingly documented, "mixoplankton", a third category separated from the traditional categorization of plankton into "phytoplankton" and "zooplankton", has become a new paradigm and research hotspot in aquatic plankton ecology. While species of dinoflagellates are a dominant group among all recorded members of mixoplankton, the trophic modes of Karlodinium, a genus constituted of cosmopolitan toxic species, were reviewed due to their representative features as mixoplankton and harmful algal blooms (HABs)-causing dinoflagellates. Among at least 15 reported species in the genus, three have been intensively studied for their trophic modes, and all found to be phagotrophic. Their phagotrophy exhibits multiple characteristics: (1) omnivority, i.e., they can ingest a variety of preys in many forms; (2) flexibility in phagotrophic mechanisms, i.e., they can ingest small preys by direct engulfment and much bigger preys by myzocytosis using a peduncle; (3) cannibalism, i.e., species including at least $K$. veneficum can ingest the dead cells of their own species. However, for some recently described and barely studied species, their tropical modes still need to be investigated further regarding all of the above-mentioned aspects. Mixotrophy of Karlodinium plays a significant role in the population dynamics and the formation of HABs in many ways, which thus deserves further investigation in the aspects of physiological ecology, environmental triggers (e.g., levels of inorganic nutrients and/or presence of preys), energetics, molecular (genes and gene expression regulations) and biochemical (e.g., relevant enzymes and signal molecules) bases, origins, and evaluation of the advantages of being a phagotroph.
\end{abstract}

Keywords: Karlodinium; trophic modes; phagotrophy; mixotrophy

\section{Introduction}

Microalgae are an important group in terms of global primary productivity. Those microalgae that spend their time on vegetative growth in the water column are categorized as phytoplankton, a counterpart of zooplankton in aquatic ecology [1]. As the terms imply, autotrophy or phototrophy is the most important trophic mode in microalgae or phytoplankton and thus the focus of research on microalgae [1-3], which is reasonable and fair in terms of their major function in aquatic ecosystems as primary producers. However, other trophic modes have been found in many groups or species of microalgae and have attracted increasingly more attention from the scientific community during the last several decades because these non-autotrophic modes have been, or will be, proven to be vital strategies for the population survival and development (e.g., blooms) of phytoplankton [4].

Among 2400 valid species of dinoflagellates, about 50\% are strictly heterotrophic, while the other half of species obtained and maintained the ability of photosynthesis [5]. 
Independent of the number of species, these photosynthetic dinoflagellates occupy an essential place in primary production, particularly in coastal and estuarine ecosystems [6]. As the dark facet of primary producers, dinoflagellates are also the crucial perpetrators of harmful algal blooms (HABs) forming species, given that they are responsible for $75 \%$ of documented HABs [7]. However, intriguingly, photosynthetic dinoflagellates are generally of relatively lower photosynthetic capacity per unit of biomass and exhibit lower growth rates in comparison to many of their competitors, such as diatoms [8,9]. Thus, dinoflagellates must have other strategies to balance this competitive disadvantage. Mixotrophy, a nutritional strategy by which organisms are able to obtain nutrients and/or energy by both phototrophic autotrophy and heterotrophy [10-12], is one of these strategies that enhance growth rates via obtaining energy from either dissolved organic compounds [13] or particulate preys [14]. The mixotrophic protists that play roles of both primary producer and consumer have been widely investigated from different aspects [11,12].

The genus Karlodinium J. Larsen was erecteded from the genus Gymnodinium in 2000 because of the characteristics of their apical groove, ultrastructure, and partial large subunit rDNA sequences [15]. Species of Karlodinium are well known for forming HABs and thus causing the consequent fish-killing events [16-18]. The genus includes at least 15 species to date (Table 1). The distribution of the genus Karlodinium spreads over four oceans [16] (also see Ocean Biogeographic Information System, https:/ / obis.org/taxon/23 1789). Karlodinium veneficum (original name: Gymnodinium veneficum; synonym: Karlodinium micrum, Gymnodinium micrum, Gyrodinium galatheanum, Woloszynskia micra, and Gyrodinium estuariale) is the type species and also the most intensively and extensively investigated one in the field and the laboratory [19-23]. Species in the genus of Karlodinium, such as K. veneficum, K. armiger, K. corsicum and K. aculat, have been reported to be associated with many toxic events and caused mortality of fishes, mussels and zooplanktons [18,24-30]. Multiple types of toxins have also been detected from these species. The toxins produced by $K$. veneficum are termed as karlotoxins [25] and at least 12 natural analogs of karlotoxins have been identified to date [25,31-33]. Karlodinium conicum was also proved to produce karlotoxin [34,35]. From K. armiger, however, a different species of toxin, karmitoxin, has been chemically characterized [36,37]. Besides, the presence of some types of NSP toxins in K. corsicum has also been testified by mouse tests [27]. 
Table 1. A collection of Karlodinium species regarding their bloom threat, toxicity, trophic modes, and associated mechanisms.

\begin{tabular}{|c|c|c|c|c|c|c|c|c|}
\hline Species & $\begin{array}{c}\text { Former names } \\
\text { and/or taxonomic } \\
\text { synonyms }\end{array}$ & Distribution & Blooms & Toxicity & Autotrophy & Osmotrophy & Phagotrophy & $\begin{array}{l}\text { Peduncle-like } \\
\text { structure }\end{array}$ \\
\hline K. armiger & 1 & $\begin{array}{c}\text { Alfacs Bay, Ebro } \\
\text { Delta, NW } \\
\text { Mediterranean } \\
{[38]}\end{array}$ & Yes $[29,39]$ & $\begin{array}{c}\text { Yes (Karmitoxin) } \\
{[37]}\end{array}$ & Yes & $?$ & Yes $[40,41]$ & $\begin{array}{c}\text { Have a peduncle } \\
{[38]}\end{array}$ \\
\hline K. australe & 1 & $\begin{array}{c}\text { North-eastern } \\
\text { Tasmania, Port } \\
\text { Phillip Bay } \\
\text { (Victoria), South } \\
\text { Australia and } \\
\text { TuggerahLakes } \\
\text { [28] and Singapore } \\
\text { [42,43] }\end{array}$ & Yes [18] & Yes $[18,28]$ & Yes [28] & $?$ & Yes [28] & $\begin{array}{l}\text { Have a thick, } \\
\text { tubular } \\
\text { peduncle-like } \\
\text { structure [28] }\end{array}$ \\
\hline K. antarcticum & $\backslash$ & $\begin{array}{c}\text { Southern Ocean } \\
{[43]}\end{array}$ & $?$ & No [34] & Yes [43] & $?$ & $?$ & $\begin{array}{c}\text { Have a } \\
\text { tube-shaped } \\
\text { structure [43] }\end{array}$ \\
\hline K. ballantinum & $\backslash$ & $\begin{array}{l}\text { Mercury Passage, } \\
\text { Tasmania, } \\
\text { Australia, and } \\
\text { Tyrrhenian coastal } \\
\text { waters [43] and } \\
\text { the Mexican } \\
\text { Pacific [45] }\end{array}$ & $?$ & $?$ & Yes & $?$ & $?$ & $\begin{array}{c}\text { Have a } \\
\text { tube-shaped } \\
\text { structure [43] }\end{array}$ \\
\hline K. conicum & 1 & $\begin{array}{c}\text { Southern Ocean } \\
{[43]}\end{array}$ & $?$ & Yes (KmTx) [34] & Yes & $?$ & $?$ & $\begin{array}{c}\text { Have a } \\
\text { tube-shaped } \\
\text { structure [43] }\end{array}$ \\
\hline K. corrugatum & $\backslash$ & $\begin{array}{c}\text { Southern Ocean } \\
{[43]}\end{array}$ & $?$ & No [34] & Yes & $?$ & $?$ & $?$ \\
\hline
\end{tabular}


Table 1. Cont.

\begin{tabular}{|c|c|c|c|c|c|c|c|c|}
\hline Species & $\begin{array}{c}\text { Former names } \\
\text { and/or taxonomic } \\
\text { synonyms }\end{array}$ & Distribution & Blooms & Toxicity & Autotrophy & Osmotrophy & Phagotrophy & $\begin{array}{l}\text { Peduncle-like } \\
\text { structure }\end{array}$ \\
\hline K. corsicum & $\begin{array}{l}\text { Gyrodinium } \\
\text { corsicum }\end{array}$ & $\begin{array}{c}\text { Corsica (France), } \\
\text { Tyrrhenian Sea } \\
\text { and the Spanish } \\
\text { Alfacs Bay of } \\
\text { Mediterranean Sea } \\
{[29,46]}\end{array}$ & Yes [24] & Yes [26] & Yes & $?$ & $?$ & $\begin{array}{c}\text { Have a ventral } \\
\text { plate [47] }\end{array}$ \\
\hline K. decipiens & Karenia digitate & $\begin{array}{c}\text { from coastal } \\
\text { Tasmania } \\
\text { southward to the } \\
\text { north polar front, } \\
\text { and western } \\
\text { European Atlantic } \\
\text { waters (Bilbao, } \\
\text { Spain) [43] }\end{array}$ & $?$ & No [34] & Yes & ? & $?$ & $\begin{array}{c}\text { Have a } \\
\text { tube-shaped } \\
\text { structure [43] }\end{array}$ \\
\hline K. digitatum ${ }^{1}$ & Karenia digitata & $\begin{array}{c}\text { Japan coastal } \\
\text { waters of Hong } \\
\text { Kong, Fujian and } \\
\text { Guangdong's } \\
\text { Southern, China } \\
{[48,49]}\end{array}$ & Yes [49] & Yes [49] & Yes & $?$ & $?$ & $\begin{array}{l}\text { Have small } \\
\text { finger-like } \\
\text { extensions [49] }\end{array}$ \\
\hline K. elegans & 1 & $\begin{array}{c}\text { Pingtan coastal } \\
\text { water, East China } \\
\text { Sea [50] }\end{array}$ & $?$ & No [50] & Yes [50] & $?$ & $?$ & $\begin{array}{c}\text { Have a tube-like } \\
\text { structure [50] }\end{array}$ \\
\hline K. gentienii & $\backslash$ & $\begin{array}{c}\text { The Atlantic coast } \\
\text { of Brittany [51] }\end{array}$ & Yes [51] & Yes [51] & Yes & $?$ & $?$ & $\begin{array}{c}\text { Have a } \\
\text { tube-shaped } \\
\text { structure [51] }\end{array}$ \\
\hline
\end{tabular}


Table 1. Cont.

\begin{tabular}{|c|c|c|c|c|c|c|c|c|}
\hline Species & $\begin{array}{c}\text { Former names } \\
\text { and/or taxonomic } \\
\text { synonyms }\end{array}$ & Distribution & Blooms & Toxicity & Autotrophy & Osmotrophy & Phagotrophy & $\begin{array}{l}\text { Peduncle-like } \\
\text { structure }\end{array}$ \\
\hline K. veneficum & $\begin{array}{c}\text { Gymnodinium } \\
\text { veneficum; } \\
\text { Karlodinium } \\
\text { micrum; } \\
\text { Gymnodinium } \\
\text { micrum; } \\
\text { Gyrodinium } \\
\text { galatheanum; } \\
\text { Woloszynskia micra; } \\
\text { Gyrodinium } \\
\text { estuariale [38,52] }\end{array}$ & Cosmopolitan [16] & Yes $[29,39,53]$ & Yes [54] & Yes [20] & Yes & Yes $[16,20,21]$ & $\begin{array}{c}\text { Have a peduncle } \\
\text { [38] }\end{array}$ \\
\hline K. vitiligo & $\begin{array}{l}\text { Gymnodinium } \\
\text { vitiligo ? K. } \\
\text { veneficum [38] }\end{array}$ & $?$ & $?$ & $?$ & Yes & $?$ & $?$ & $?$ \\
\hline K. zhouanum & K. jejuense & $\begin{array}{c}\text { Widely spread } \\
\text { over the coastal } \\
\text { waters of China } \\
{[55,56]}\end{array}$ & Possible [57] & $?$ & Yes [56] & $?$ & $?$ & $\begin{array}{c}\text { Tube-like structure } \\
\text { in intercingular } \\
\text { region [56] }\end{array}$ \\
\hline
\end{tabular}

Note: “" indicates none. "?" indicates that there is no explicit record in the literature. 
The trophic modes of Karlodinium have been studied for several decades, and were found to be diverse and typical. However, new findings have been made recently and improved our understanding of this genus, which comprises a group of mixoplankton. At least four Karlodinium species have been confirmed to be mixotrophic, namely K. veneficum [20,58], K. armiger [40,41], K. aculat [28] and K. azanzae [44], by now. Among these proven mixotrophic species, some exhibit plastic and multiple trophic modes, as well as wide spectrum of prey size and varieties, i.e., K. armiger and K. veneficum [16,59]. Other species, while direct evidence about their mixotrophy is lacking at present, were also reported to possess peduncle-like structures (Table 1), namely the instrument for phagotrophy, such as K. gentienii [51] and K. zhouanum [56].

Because possibly all Karlodinium species have potential for mixotrophy and the highly flexible trophic modes may be a vital trait of this and other similar groups of dinoflagellates in their ecology and evolution, here we review the knowledge advancement in understanding the trophic modes of dinoflagellates in general and Karlodinium in particular, with the hope of inspiring further investigations on the genetic, cellular, physio-chemical, and ecological mechanisms of mixotrophy in dinoflagellates (HABs-forming groups particularly) by putting forward our insights and suggestions about the interesting topic.

\section{Trophic Modes of Dinoflagellates}

In addition to autotrophy or phototrophy, many free-living dinoflagellates live as either heterotrophs or mixotrophs $[5,60]$. Mixotrophic modes can be further categorized as amphitrophic (heterotrophy or autotrophy alone is sufficient for nutrition) and mixotrophic sensu stricto (both forms of nutrition are required) [61].

Dinoflagellates have evolved multiple heterotrophic nutritional strategies [61]: (1) osmotrophy (or resorption), by which the organic macronutrients are taken up by direct passage through the plasma membrane, (2) saprotrophy, a chemoheterotrophic process of digesting organic matter extracellularly and (3) endocytosis, which includes pinocytosis (cell drink, a mode of endocytosis by which liquid organic matter is taken up into the cell by invaginating of the cell membrane, and forming a small vesicle inside the cell) and phagocytosis or phagotrophy (cell eating, the endocytosis of particulate food).

Generally, there are three types of feeding mechanisms of phagotrophy that dinoflagellates use to uptake food particles (including intact cells): (1) direct engulfment (phagotrophy sensu stricto), i.e., a cell phagocytizes an entire food particle, including the prey cell membrane $[61,62],(2)$ tube feeding, i.e., the feeding cells use an feeding appendage to suck food particles (e.g., Peridiniopsis berolinensis) [63,64], and (3) pallium feeding, i.e., some species use a feeding veil, namely pallium, to surround and digest the prey outside the cell body of the predator, then the liquefied cytoplasmic content of prey is taken up by the predator, leaving only an empty wall or frustule (e.g., Zygabikodinium lenticulatum, Oblea rotunda and Protoperidinium conicum [64-66]).

Direct engulfment, or phagocytosis sensu stricto, of dinoflagellates seems to be mainly found in athecate dinoflagellates, like Blastodiniales, Gymnodiniales, Noctilucales, and Oxyrrhinales [61,67]. However, it remains unclear whether this apparent "preference" is due to the higher flexibility or elasticity of the cells of naked species than armored species. In addition, special feeding organelles, such as tentacles, lobopodia and peduncles, were usually found in the sulcal region near the flagellar groove [61].

Tube feeding has been observed to use two types of feeding tubes in dinoflagellates: the peduncle (a protoplasmic strand protruding from the mid-ventral area of the sulcus to connect predator and prey, e.g., Paulsenella) $[61,68,69]$, and the phagopod (a noncytoplasmic feeding tube, e.g., Amphidinium cryophilum) [70]. Myzocytosis is a kind of tube feeding by which the feeding cells suck out the contents of prey cells by leaving the plasma membrane outside the predator. The prey plasmalemma is not taken up, and thus the prey cytoplasm is bounded only by the vacuolar membrane in the food vacuole. This mode of nutrition was first described in the naked dinoflagellate Gyrodinium vorax Biecheler [62]. The terminology for the uptake organelle of myzocytosis has not been uniformed, and it 
has been variously referred to as feeding tubes or peduncles [61], and in this review, we use the term "peduncle" to refer to the uptake organelle of myzocytosis. The peduncle was reported to be formed by the emergence of a preformed "microtubular basket" which consists of plates of microtubules [69,71]. Based the light and electron microscopic observations on Pausenella sp., Schnepf et al. (1985) suggested that the food uptake was driven by a hydrostatic gradient which might be attributed to rhythmical ion pumping and based on the existence of a common cavity and the sphincters [71]. In contrast to most suctorian tentacles, peduncles are generally not permanently protruded [61,69], and are usually invisible in predators not feeding on food [69]. The length of feeding tubes also differs in species and even varies in a single cell with feeding status [61]. No prey size spectra are confirmed for tube feeders in the literature, but some researchers have pointed out that the prey size seems not to have an upper limit, as studies reported the ingestion ability of $K$. veneficum and K. aculat on rotifer, copepod eggs, and even tissues of fish $[16,72,73]$. The strictly heterotrophic species Pfiesteria shumwayae was found to exhibit lethal effect on fish by myzocytosis, also named "micropredation" [74], a trophic strategy in which a predator feeds on a rather large prey and one feeding individual attacks more than one prey during its life span and attacks the prey intermittently without necessarily eliminating its fitness (e.g., mosquito) [75]. However, both direct engulfers and pallium feeders have prey size spectra restricted to the volume capacity of the predator cell [64].

The feeding processes of phagocytosis were described by several steps including pre-capture behavior, capture, and prey manipulation [64]. While in pre-capturing, dinoflagellates swimming faster than their prey are referred as the "searching type" and those being able to catch the faster-moving prey are described as the "trapping type" [64]. Search type is induced by chemical substances released from the injured prey and is independent of prey size $[63,76]$. It is demonstrated that dinoflagellates of similar size but with different speed in comparison to preys, swimming characteristics, and feeding strategies (peduncle vs. tow line) have substantially different responses to the introduction of preys [77]. The feeding dinoflagellates usually capture preys using some specialized appendages named "capture filament" or "tow filament". The capture filament of Peridiniopsis berolinensis is a thin filament that originates from the ventral region of the cell near the sulcus [63]. Once the filament anchors to the prey, it retracts, brings the prey closer to the predator (e.g., Protoperidinium and Diplosalis group) or contracts entirely, and thereby drags the prey to the sulcal region of the predator (e.g., Gyrodinium) [78]. After capturing the prey, most dinoflagellates consume the prey immediately, but the manipulation of prey may differ with other feeding mechanisms [14,78].

Certain dinoflagellates may utilize cleptochloroplasts (transiently alien chloroplasts) obtained from preys [79]; this nutrient strategy is termed kleptochloroplastidy [80]. Myzocytosis is the proven method to acquire kleptochloroplasts from preys [61,81]. Hansen (1998) reviewed a few species that lack chloroplasts but are capable of sequestering chloroplasts from other phytoplankters and then using the "stolen" chloroplasts for photosynthesis [82]. This kind of mixotrophy has been reported among some species belonging to the naked genera Amphidinium and Gymnodinium [82-84]. It is noteworthy that the latter may contain species from Karlodinium, as this genus had not been separated from Gymnodinium until 2000 [15]. Li et al. found fragmental pigments from cryptophycean prey in K. veneficum that had been ingested with the prey for $41 \mathrm{~h}$, suggesting some chloroplasts of prey could be retained by the dinoflagellate [20].

\section{Autotrophy of Karlodinium}

All Karlodinium species have the ability of photosynthesis (Table 1). Karlodinium veneficum and K. armiger are the best-studied species that have haptophyte origin chloroplasts $[20,21,40,59,85,86]$. Phototrophic growth rates of $K$. armiger are quite low (a maximum of 0.01 and $0.10 \mathrm{~d}^{-1}$ ), even at high irradiances [40,59]. In comparison, $K$. veneficum grows faster than $K$. armiger photosynthetically without prey, with growth rates ranging from 0.17 to $0.36 \mathrm{~d}^{-1}$ [87]. In some cases, the growth rate of $K$. veneficum may even elevate up to 
$0.55 \mathrm{~d}^{-1}$ in the light without prey [85]. The photosynthetic growth rate of K. veneficum is significantly affected by temperature and salinity [23]. At least some strains of K. veneficum were better adapted to "low-light" conditions than were K. armiger, whereas characteristics of $K$. armiger were more suitable to cope with "high-light" [54].

Karlodinium aculat grows poorly in the normal conditions without providing food. The monoculture of K. australe grown in laboratory and Gse medium stabilized at low concentrations $\left(10^{2}-10^{3}\right.$ cells $\left.\mathrm{mL}^{-1}\right)$ and failed to reach higher cell concentrations [28]. Lim et al. obtained similar results from a K. austral bloom in the cage-farming region of the West Johor Strait of Malaysia $\left(0.31-2.34 \times 10^{3}\right.$ cells $\left.\mathrm{mL}^{-1}\right)$. However, K. veneficum could reach extremely high cell densities $\left(2-3 \times 10^{5}\right.$ cells $\left.\mathrm{mL}^{-1}\right)$ in laboratory cultures [88]. These observations suggest that different species of Karlodinium may also differ in their phototrophic growth potential. In contrast to the relatively poor autotrophic ability, the genus is successful in forming harmful blooms. Thus, other nutritional strategies may play a key role in population competition and deserve further investigation.

\section{Osmotrophy of Karlodinium}

Osmotrophy, i.e., the uptake of dissolved organic compounds, has been shown to be an efficient nutritional strategy for algae. Karlodinium veneficum is the most studied species in Karlodinium on osmotrophy. Cell-surface proteolytic activity (leucine aminopeptidase) was detected in K. veneficum and suggested to play a role in obtaining nutrition by obtaining amino acids for assimilation, while, alternatively, released amino acids may be degraded by cell-surface amino acid oxidases to provide ammonium, which can be assimilated as a source of nitrogen [89]. Solomon and Glibert found that urease activity in K. veneficum was significantly higher than that in other species (including Heterocapsa triquetra, the cryptophyte Storeatula major, and the haptophyte Isochrysis sp) on both a per cell basis and a per cell volume basis [90]. Harmful dinoflagellates like K. veneficum may be better suited to utilize urea than other species do according to their high urease activity and large intracellular urea pools, which may explain why these harmful dinoflagellates proliferate rapidly in the water bodies with plenty of urea [90].

Osmotrophy may be an important and ubiquitous trophic strategy for all species in Karlodinium, because almost all phytoplankton are osmotrophs in some parts, not least by virtue of being auxotrophic; many need external sources, e.g., vitamins [91]. Phytoplankton exhibit non-auxotrophic osmotrophy to a significant level, mostly in relation to the uptake of primary metabolite compounds, especially amino acids [54]. It has been reported that many dissolved organic compounds, such as amino acids (e.g., glutamine, leucine, thymidine, aspartic acid), carbohydrates (e.g., glucose) and other organic compounds (e.g., acetic acid, coumaric acid, glycerol), can be used as carbon and nitrogen sources, which are commonly released by the algae themselves or bacteria [92-96].

\section{Phagotrophy of Karlodinium}

\subsection{Karlodinium veneficum}

Karlodinium veneficum exhibited increased ingestion rate on eubacteria when phosphate was limited, which may be an important nutrient-acquiring strategy when inorganic nutrient is limited [97]. Karlodinium veneficum was also reported to ingest various kind of small algae by phagocytosis, including Chroomonas salina, Cryptomonas appendiculata, C. calceiformis, C. maculata, Hemiselmis brunnescens, H. rufescens, Hemiselmis sp., Rhinomonas reticulata, Rhodomonas salina, Rhodomonas sp., Storeatula major, and Isochrysis galbana, and most of them are cryptophytes $[20-22,85,86,98,99]$. The direct engulfment of whole cells of Storeatula major, a species of cryptophyte, by $K$. veneficum and the associated feeding processes were initially documented via video recording under light microscope [20]. This phagocytosis process was described to have three typical steps [20]: (1) Pre-capture behavior. After adding cryptophyte as prey, most K. veneficum cells increased the swimming speed, and some began to swim around the prey; (2) Capture. Generally, K. veneficum cells formed a protrusion, which was near the flagellar pores in the sulcal region, and attached to the prey. Once the protrusion contacted the prey cell, phagocytosis began. 
In some cases, a thin capture filament projected from the extending sulcal region in the epicone was observed, and then the filament captured and drew the prey cell to the surface of the dinoflagellate in the sulcal region (Figure 1a, SEM micrographs were adopted from Place et al. (2012) [72]; (3) Prey manipulation. After capturing prey firmly, K. veneficum usually stopped swimming to draw the whole cell of prey into the dinoflagellate cell through the protrusion. During the process of feeding, a "feeding gap" appeared to form along the cingulum near the flagellar pores and a pair of "lip-like" protrusions (i.e., peduncle) was observed (Figure 1b) [20]. The engulfment behavior usually took 2 to $3 \mathrm{~min}$ at room temperature $\left(20^{\circ} \mathrm{C}\right)$ and, when the ingestion was completed, $K$. veneficum cells resumed swimming and were able to find and phagocytize another prey cell.

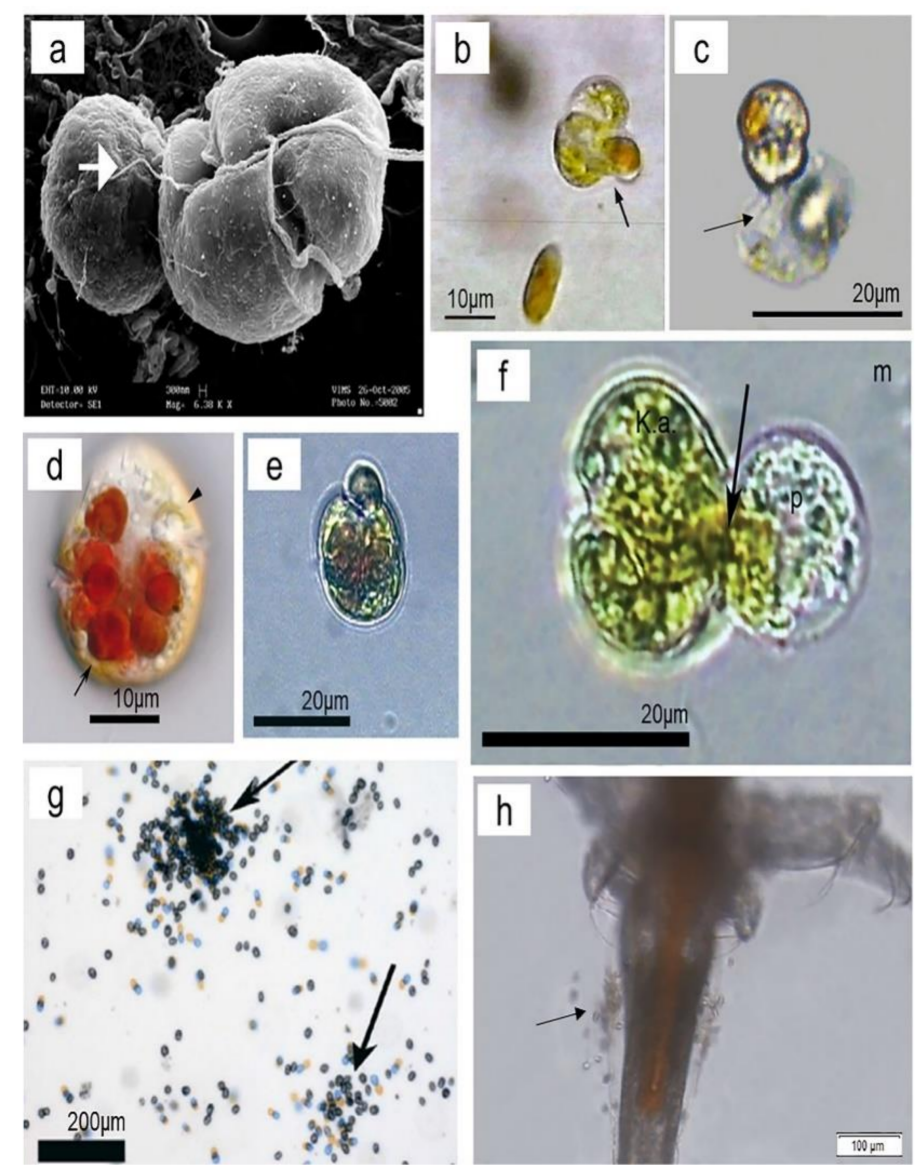

Figure 1. The phagotrophic behavior of Karlodinium. (a) SEM of K. veneficum feeding on Rhodomonas sp. The thin filament is marked with an arrow (the photo was modified from Place et al. [72]). (b) A cell of K. veneficum was engulfing whole cells of Storeatula major. The "lip-like" protrusion was observed to gradually move laterally along the prey surface, which causes further engulfment of the prey cell (the photo was modified from Li et al. [20]). (c) Karlodinium veneficum ingest a dead cell of con-species by myzocytosis using peduncles. Karlodinium veneficum was searching for cytoplasm by opening the peduncle (arrow) widely in the dead cell (the photo was modified from Yang et al. [16]). (d) Subsurface ventral view of K. australe after feeding overnight on Rhodomonas salina. Note light yellow-green chloroplasts (arrowhead) and red food vacuoles (arrow, the photo was modified from de Salas et al. [28]). (e) Karlodinium armiger was ingesting the cryptophyte Rhodomonas salina by direct engulfment (the photo was modified from Berge et al. [59]). (f) Karlodinium armiger was ingesting the raphidophyte Fibrocapsa japonica (p) by myzocytosis (the photo was modified from Berge et al. [59]). The peduncle was shown by the arrow. (g) Aggregations (arrows) of K. armiger cells in cultures fed the thecate dinoflagellate Prorocentrum minimum (the photo was modified from Berge et al. [59]). (h) Aggregations (arrows) of K. veneficum cells fed an injured brine shrimp Artemia salina (the photo was modified from Yang et al. [16]). 
Sheng et al. also represented the phagocytosis process of K. veneficum on Storeatula major and paid more attention to its pre-capture behavior. When presented with $S$. major, the velocity, radius, and pitch of $K$. veneficum reduced, but its angular velocity increased [58,77]. The feeding cells of $K$. veneficum significantly reduced their usual vertical migration, probably to remain in the vicinity of their preys [58,100].

A peduncular microtubular strand was observed in K. veneficum cells and believed to be a tube feeder; however, the small sized preys such as eubacteria and cryptophytes were obviously ingested by direct engulfment [20,58], indicating an alternative function of the microtubular strand. Although K. veneficum was also observed to have the potential to feed on the diatom Melosira and copepod Acartia tonsa [72], direct evidence of feeding behavior using peduncles has not been captured. Recently, we observed K. veneficum ingested preys via myzocytosis using the peduncle [16], in which the entire feeding process was much the same as that observed in direct engulfment except that only the cytoplasm of prey (cells or larger multicellular individuals) was sucked into K. veneficum cells through the peduncle in myzocytosis (Figure 1c) and the time expenditure of myzocytosis, which varied from several seconds to a few minutes, was relatively shorter than that of the direct engulfment on small-sized prey [16]. As the ingestion proceeded, the cell volume of K. veneficum gradually increased [16]. Profiting by this mechanism, the prey size spectra would have no upper limit. We demonstrated that $K$. veneficum is virtually an omnivorous feeder, as it could feed on both live and dead bodies/cells of phytoplankton (the dinoflagellates Margalefidinium polykrikoides, Akashiwo sanguinea, and Alexandrium leei, the cryptophyte Rhodomonas salina, and the haptophyte Isochrysis galbana) and animals (the finfish Oryzias melastigma, brine shrimp Artemia salina, and rotifer Brachionus plicatilis). Importantly, K. veneficum also exhibited cannibalism (i.e., feeding on dead cells of its own species), which implies that the dead and weak cells of $K$. veneficum can be ingested by the live cells to recycle nutrients contained in the eaten cells [16]. Cannibalism is one of the simplest trophic interactions [101]. The advantageous aspect of this particular type of phagotrophy is that it allows an efficient nutrient transfer because of the well-matched nutritional value between the food and consumer [102]. We also observed that K. veneficum could survive at a lower cell density, without inorganic nutrients supplementing the culture medium, for a year, which was obviously attributable to the cannibalistic phagotrophy [16]. Cannibalism was also observed in Protoperidinium when cell abundances were high, and in Oxyrrhis when "victim" and "cannibal" differed in sufficient cell size-classes [66,102]. These observations suggest that cannibalism may be a mechanism of withstanding prolonged starvation.

The ingesting ability of $K$. veneficum is affected by environmental factors such as irradiance. It was observed that $K$. veneficum did not exhibit phagocytosis without light and the ingestion rate increased drastically when irradiance rose up to $\sim 50 \mu \mathrm{mol}$ photons $\mathrm{m}^{-2} \cdot \mathrm{s}^{-1}$ [20].

\subsection{Karlodinium australe}

Karlodinium australe has also been known to phagocytize particulate foods in food vacuoles since the species was initially described [28]. A thick and tubular pedunclelike structure of this organism was observed in the sulcal region [28]. Phagotrophy in K. australe was captured when autotrophically grown cultures were provided with live $R$. salina cells as food (Figure 1d) [28]. However, the intact feeding behavior has not been captured. A recent study further investigated the feeding mechanism and ecological implication of the phagotrophic mixotrophy of K. australe. Karlodinium australe is a phagotroph that can ingest preys via direct engulfment or tube feeding. In accord with its flexible phagotrophic modes, K. australe is also an omnivorous mixotroph. Except R. salina, a diverse range of organisms could be ingested, such as microalgae (Isochrysis galbana, Margalefidinium polykrikoides, Karenia mikimotoi and Gymnodinium catenatum) and zooplankton (Artemia salina and Brachionus plicatilis) [73]. 


\subsection{Karlodinium armiger}

Karlodinium armiger is an omnivorous and obligate mixotroph. It seems that K. armiger obtain essential growth factor or substance through phagotrophy [59]. This species can ingest many types of preys (except for almost all Bacillariophyceae tested), but yield the highest growth rates when offered cryptophytes as prey [40,59]. However, K. armiger cannot grow and survive by feeding in complete darkness or at dim light, even by feeding adequate amounts of preys regularly [59], indicating that $K$. armiger cannot grow on as complete phagotrophy.

Under light microscope, the feeding mechanism of K. armiger was occasionally assumed to be direct engulfment (i.e., phagocytosis sensu stricto) while it was feeding on small-sized cells of prey; however, it would use tube feeding (myzocytosis) when the preys were larger or thecate [59]. Rigid cell coverings seem to set a barrier to grazing; thus, species like diatoms and thecate dinoflagellates may not be appropriate food [59].

Some details of the phagotrophy process in K. armiger were also documented by Berge et al. [59]: K. armiger also displayed distinct and intense pre-capture behavior by increasing swimming speed and frequently changing swimming direction before ingestion. This pre-capture swimming behavior has also been documented in other phagotrophic dinoflagellates $[63,76,103,104]$. The predator cell usually encountered a prey cell with its apical part. After contacting with a prey cell, the predator slowed down the swimming speed. During this stage, less than half of the prey cells (R. salina) were captured. Occasionally, a capture filament, an up to $10 \mu \mathrm{m}$ long structure, which has also been reported in other phagocytosing dinoflagellates, such as Peridiniopsis berolinensis [63] and K. veneficum [19,20], was observed to attach the prey. When the capture succeeding, the predator placed its sulcal area, where the phagocytosis took place, facing the prey and revolved around its anterior-posterior axis. During this feeding stage, a small protrusion sometimes appeared. However, most preys and predators often established close contact immediately without any signs of protrusion. Often, the whole Rhodomonas cell was apparently engulfed or sucked into a food vacuole (Figure 1e) [59]. Occasionally, the cytoplasm was separated from the periplast of cryptophyte and taken up through the sulcus, leaving the periplast behind [59].

However, it differed somewhat from the feeding sequence of ingesting intact cells of $R$. salina when the predator cells fed on relatively large preys $(>10 \mu \mathrm{m})$. During feeding on large preys like the raphidophyte Fibrocapsa japonica, only a small part was sucked into a food vacuole. The cytoplasm separated from the cell membrane of the prey and flowed into food vacuoles of the predator through a narrow part (3-4 $\mu \mathrm{m}$ thickness) of the sulcal area (Figure 1f) [11]. This behavior resembled myzocytosis or tube feeding [59].

Karlodinium armiger feeds on preys using an unnoticeable feeding tube (peduncle) which allows for ingestion of larger food particles [59]. However, Bergholtz et al. reported the presence of a peduncular microtubular strand in K. armiger [38]. The optimal prey size for K. armiger was about $13 \mu \mathrm{m}$, a size class which is close to the predator and contributes higher ingestion rates. Smaller preys $(<8 \mu \mathrm{m})$ resulted in lower ingestion rates $(20-24 \mathrm{pg} \mathrm{C}$ cell $\left.{ }^{-1} \cdot \mathrm{d}^{-1}\right)$, but still contributed to fairly high growth rates $\left(0.35-0.45 \mathrm{~d}^{-1}\right)$. Although $K$. armiger can feed on preys in a large size spectrum [40], maximum growth rates relied more on prey taxa (cryptophytes) rather than on prey size when the food was saturated [40].

Several cells of K. armiger often attacked and fed on prey cells simultaneously [59]. When $K$. armiger reached higher cell densities, aggregates of predator cells swarming intensely around prey cells were easily recognized (Figure 1g) [71]. Aggregates led to fairly high swimming speeds of other K. armiger cells in the culture as these cells were obviously attracted to the preys. Such aggregation of predator cells around prey indicated a chemical attraction. Both mobile and immobile cells were observed to be captured and ingested [59]. We also observed the same aggregation of predator cells around a prey in K. veneficum (Figure 1h) [16].

The feeding mechanism of $K$. veneficum and $K$. armiger indicates that mixotrophic species of Karlodinium may be omnivorous phagotrophs with a relatively wide range of 
prey species and prey size spectrum than previously recognized. A newly identified species, K. azanzae, was also demonstrated to be phagotrophic and able to feed on invertebrates by micropredation [44]. However, direct evidence of myzocytosis feeding, for most other species of Karlodinium, has been absent. Whether the presence or absence of a trophic mode-relevant trait in one, but not in another, species of Karlodinium was really caused by interspecific genetic differences, or was due to imbalanced investigations, definitely deserves more intensive study.

\section{Evolution of the Feeding Mechanisms in Karlodinium}

The feeding mechanism of Karlodinium seems to be plastic and of more than one type (e.g., K. veneficum feeding by direct engulfment and myzocytosis). According to most studies, only one feeding mechanism was found in a given dinoflagellate species [64]. The flexible feeding mechanisms of Karlodinium may lead a new discovery and provide a novel view of the evolution of feeding mechanisms in dinoflagellates, but it is clear that this aspect cannot be adequately summarized due to the current status of knowledge.

Cannibalism of other dinoflagellates has been reported, such as Fragilidium, Peridiniopsis, Protoperidinium, Pfiesteria, and Oxyrrhis $[63,66,102,105-107]$ and may be widespread in more dinoflagellates, particularly those that are strictly heterotrophic. Cannibalism has been speculated to have particular implications during the evolution of sex because self-ingestion without self-digestion may have led to the evolution of diploidy [108].

Phagotrophy, the internalization of photosynthetic organisms by a eukaryote in a general sense, is essential for the occurrence of present-day endosymbiotic algae and kleptoplastid-containing protists, and even for the origin of plastids themselves [109]. Analysis of field data revealed that up to $40-60 \%$ of plankton which have been traditionally labelled as microzooplankton (non-) are actually non-constitutive mixotrophs. They are mixotrophs lacking a constitutive ability of photosynthesis, and thus, can employ acquired chloroplastids for phototrophy other than phagocytose for nutrients [110]. It is interesting that the evolutionary histories of chrysophytes and dinoflagellates, two groups containing the largest amounts of phagotrophic species, can be traced back to the early Paleozoic [111]. This suggests that mixotrophy, or multiple trophic modes, may be a primitive state, and also be indispensable for long term evolutionary success [112]. However, this aspect largely continues to be an unexplored area.

There may be close relationships between phagotrophy and toxicity/allelopathy of $K$. veneficum. Phagotrophy could not be an isolated aspect of the physiological ecology of phytoplankton. It may have coevolved with other physiological capabilities in many taxa, such as the ability to use dissolved organic material and allelopathic tendencies [113]. Many toxic algae have been proved to be phagotrophic or closely related to the known phagotrophs. The toxicity of $K$. veneficum in different strains exhibited a decreasing order that perfectly coincided with the increasing order of laboratorial culturing time [88]. It seems that the toxicity of $K$. veneficum may have receded because of the lack of prey.

\section{Mixotrophy in Regulating Population Dynamics and HABs Formation of Karlodinium}

The significance of mixotrophy in phytoplankton has been increasingly emphasized in recent years. In 2016, a new functional grouping of planktonic protists in an ecophysiological context was proposed to recognize the value of mixotrophy in euphotic aquatic systems and to align with the traditional dichotomy of phytoplankton and zooplankton: (1) phagoheterotrophs as protists lacking photosynthetic autotrophic capacity, (2) photoautotrophs as protists lacking phagotrophic capacity, (3) constitutive mixotrophs (CMs) as phagotrophs with an inherent capacity for phototrophy, and (4) non-constitutive mixotrophs (NCMs) as phagotrophs acquiring their phototrophic capacity by ingesting specific (SNCM) or general non-specific (GNCM) preys [114]. Given that mixotrophs differ widely in their biology, it is apparent that they are also different in their ecological niche and their implications on ecosystem processes [115]. CMs, combining functions of both phagotrophy and phototrophy, are supposed to have the capability to hold the high ground in an ecosystem, 
ultimately triggering a large area of blooms. Indeed, constitutive mixotrophy has been considered as a major trophic mode for harmful dinoflagellate species in eutrophic coastal waters [4]. Moreover, mixotrophic species tend to dominate in more-mature systems, such as established eutrophic systems and oligotrophic systems in temperate summer, with their flexible nutritional supplies [116]. The mixotroph-dominated ecological structure differs radically in energy flow and material cycling, which is reflected in the shortened and more efficient transformation from nutrient regeneration to primary production. In severe eutrophic water bodies, bloom-forming phytoplankton with mixotrophic mode may sometimes decrease energy flowing to higher trophic levels and thus simplify the food web [115]. Moreover, mixotrophic protists can also take advantage of bacterial production to support primary production [116]. In view of the important role of mixotrophic protists in the marine ecosystem, "mixoplankton" was proposed and emphasized as a new paradigm for marine ecology and is believed to offer a better understanding on the microbial trophic dynamics and the biological pump, along with "phytoplankton" and "zooplankton" [116,117]. This conception may become a new research hotspot.

Mixotrophy is supposed to be a major contributor to the population dynamics of the Karlodinium species. Dinoflagellates with different trophic modes may indicate that they employ different survival strategies and occupy different ecological niches, and the phagotrophic tendencies of Karlodinium may partially explain some aspects of their bloom dynamics and population ecology. On one hand, phagotrophy may play an important role for phagotrophs in maintaining their population in environments of low light intensity and low nutrient availability [118] via acquiring limiting elements from prey. On the other hand, even in eutrophic habitats, phagotrophic mixotrophs may attain growth higher than that which they could reach in a strict phototrophic mode [4]. Phagotrophy can also contribute to a better budget of essential and major nutrients $(C, N$ and $P$ ) in these species. It was documented that the prey-ingestion of $K$. armiger helped to acquire essential inorganic nutrients to stimulate the photo-synthetic capability under nutrient limitation, as it grew very slowly in standard growth medium (f/2) and light without prey, but grew dramatically faster $\left(\mu=0.65 \mathrm{~d}^{-1}\right)$ when fed preys [119]. Karlodinium veneficum also grew much faster with prey than it did strictly autotrophically [20,85]. Adolf et al. studied the balance of autotrophy and heterotrophy of mixotrophic growth of K. veneficum [85]. It turned out that the mixotrophic growth of K. veneficum was dominated by heterotrophic metabolism, and photosynthesis continued at a lower rate, suggesting a shift toward heterotrophy during grazing. It is confirmed that photosynthesis contributed $27-69 \%$ of the gross $C$ uptake with an irradiance at $200 \mu \mathrm{mol}$ photons $\mathrm{m}^{-2} \cdot \mathrm{s}^{-1}$ and a daily supply of prey cells [85].

Multiple studies have pointed out that the predation of phagotrophic bloom-forming species on their competitors or potential grazers may contribute to the success in monopolizing resources and forming dense, mono-specific blooms [113,118]. A recent bioassay suggests that phagotrophy or micropredation of $K$. australe might play a key role in the lethal effects on the marine animals rather than exotoxicity, especially at lower cell densities [73]. This may explain why many groups of autotrophic phytoplankton can grow rapidly and densely under a combination of light and nutrients in the laboratory but most of them cannot form monospecific blooms in the field [113]. Mixotrophic Karlodinium species also show a growth advantage in size [20,59]. For example, in K. armiger cultures with sufficient food, it was easy to reach a cell size of up to $9000 \mathrm{\mu m}^{3} \cdot \mathrm{cell}^{-1}$, and the mean biovolume was approximately twice the size (2500-3000 $\left.\mu \mathrm{m}^{3} \cdot \mathrm{cell}^{-1}\right)$ of non-fed cultures (1200-1500 $\mathrm{\mu m}^{3} \cdot$ cell $^{-1}$ ) [11]. Magnifying cell size may help to avoid part of predators specializing in smaller preys. More importantly, the large range of prey types, wide spectrum of prey size, and flexible nutritional modes of Karlodinium, such as K. armiger and K. veneficum, seems to make it a powerful competitor in marine plankton [4].

HABs of Karlodinium have been demonstrated to be highly related to mixotrophic predation. Adolf et al. suggested that prey abundance, especially the abundance of nanoplanktonic cryptophytes, was a key factor stimulating the formation of toxic K. veneficum blooms in eutrophic waters [86]. They also stated the key elements resulting in toxic 
K. veneficum blooms, include (1) eutrophic environments, (2) co-occurrence of cryptophytes and K. veneficum, (3) a rapid response of cryptophytes to environmental opportunities (e.g., nutrient input) to bloom, and (4) mixotrophic predation of K. veneficum on cryptophytes, aided by allelochemicals (e.g., karlotoxins) produced by K. veneficum that improve prey capture and reduce grazing mortality of toxic strains [1].

Toxins and/or allelochemicals are involved in prey capture in this genus. Both $K$. veneficum and $K$. armiger were observed to immobilize preys by toxins, and then an ingestion process followed $[41,58]$. HABs of $K$. veneficum were assisted by karlotoxins and contributed to accumulations of toxic $K$. veneficum based on their relatively higher phagotrophic capacity compared to non-toxic cells. High densities of $K$. veneficum, when harmful blooms occurred, exhibited allelopathy to other co-occurred algae by suppressing their physiological activity and growth rates $[19,88,120]$, which induced other microalgae species more favorable to being captured.

It was assumed that once the mixotrophic harmful algal population has reached bloom density, mixotrophic feeding may not play a key role because preys were significantly reduced [121]. However, cannibalism, the recently found nutrient mode in K. veneficum, may help in maintaining population levels after the bloom is formed by consuming the dead cells of their own species [49]. This may explain the unusual phenomenon that certain harmful algal blooms maintain high cell densities even when nutrients are exhausted [122].

Based on the significant role of mixotrophy in bloom formation and dynamics in general, many new factors should be taken into consideration when we attempt to prevent and control HABs caused by mixoplankton. For instance, elimination of inorganic nutrient loading may not work well for this type of bloom. Other than inorganic nutrients and hydrological conditions, factors such as dissolved organic matter and even co-occurring plankton species could contribute to the formation of these blooms. In addition, the elimination of HABs desiderates a healthy ecosystem and complex food web, because the more energy flows to higher trophic levels, the less energy mixotrophs can detain.

\section{Perspectives for Future Investigations on the Mixotrophy in Karlodinium \\ 8.1. The Ecophysiology of Karlodinium Under Global Changes}

Mixotrophy constitutes an energy-saving and a compensatory mechanism to meet the cellular $C$ demands, thereby gaining the necessary energy to cope with the abiotic stress such as cooling and warming under the ultraviolet portion of the spectrum [123]. This metabolic flexibility implies a competitive advantage under multi-driver conditions compared with strict phototrophic or heterotrophic metabolisms as it would allow them to acquire energy and nutrition from both sun and prey depending on the environmental conditions [123]. Thus, more studies ought to be carried out to evaluate the influences of global change on the ecophysiology of mixoplankton, such as Karlodinium species.

\subsection{Molecular Basis of Phagotrophy-Relevant Genes in Karlodinium and Other Species}

At present, we know few details about the molecular or genetic mechanisms involved in mixotrophs in modulating their photoauto- vs. phagohetero-trophic capabilities [114]. The environmental changes may play an important role in impacting the metabolic regulation of mixotrophs under stressful conditions, which need to be taken into account. It was demonstrated that the phagotrophy intensity of Karlodinium species increases under nutrient limitation $[16,22,119]$. Other factors such as prey density, prey species, nutrient concentration, water depth, and salinity were also observed to affect the switch and intensity of phagotrophy $[16,21]$. We have recently documented that the intensity of phagotrophy in $K$. veneficum, including cannibalism, changed with the growth stage [16]. However, how the change in phagotrophy intensity and the switch among feeding mechanisms are regulated at subcellular and genetic levels continues to be a "Blackbox". Previous studies on the molecular and genomic mechanisms of phagocytosis were based on and limited to a small part of organisms from other groups, like the specialized phagocytotic cells of insects and mammals (e.g., macrophages), the amoebozoans Dictyostelium discoideum 
and Entamoeba histolytica, and the ciliate Tetrahymena thermophila [124-128]. The molecular studies of phagocytosis in marine microalgae are rare and focus on non-dinoflagellates like the chlorophyte Cymbomonas tetramitiformis and chrysophyte Ochromonas sp. [129,130]. Considering the possibly early origin of phagotrophy and the relatively close evolutionary distances within protists, the knowledge obtained from these molecular studies on protists, ciliates in particular, should be a solid basis for generating testable hypotheses about the molecular mechanisms of phagotrophy in Karlodinium. Nevertheless, it is now the time to start investigations on the phagotrophy-relevant genes and their expression regulations, and the biochemical (e.g., enzymes, proteins, and signal chemicals) and cellular mechanisms in Karlodinium.

\subsection{Energetics and Pathways Relevant to the Energy Metabolisms of Phagocytosis of Karlodinium}

Once organic particles, as above mentioned, are ingested as foods into Karlidinium cells, these "particles" should be subsequently degraded and utilized via a series of energy metabolism-related pathways. In addition, ingestion of organic particles may exert an influence on other metabolic pathways. A transcriptomic analysis about the effects of light and prey availability on the global gene expression of a mixotrophic chrysophyte Ochromonas sp. demonstrated that the ingestion of bacterial prey resulted in prominent changes in major metabolic pathways of carbon and nitrogen [130]. With the very limited knowledge regarding to the molecular processes involved in phagotrophy of Karlodinium, we postulate that studies focusing on the energetics and energy metabolism pathways involved in phagocytosis may be a key step to comprehensively understand the molecular processes and ecological significance of phago-mixotrophy in Karlodinium.

\section{Conclusions}

Although Karlodinium as a group of small, unarmored dinoflagellates has been long overlooked, owing to the difficulty in identification, and the nutritional modes have been far less studied for most species of the genus, our current knowledge about the trophic modes of Karlodinium is worthy of a synthesis, as has been done in this review, to promote forward studies. Karlodinium species exhibit plastic and multiple trophic modes and switching between these modes allows Karlodinium species to use inorganic and organic, dissolved and particulate nutrients, and live and dead organisms, as nutrients, and even those contained in other individuals of the same species, via multiple instruments (e.g., peduncle and capture filament) and processes (e.g., engulfment, myzocytosis, etc.). Karlodinium species may not be able to survive well in any single mode, but the mixotrophic strategy certainly provides competitive advantages over other strictly autotrophic or heterotrophic competitors, by obtaining nutrients from multiple sources and killing competitors and even predators. In addition, the synergism among toxicity and allelopathy found at least in K. veneficum may also help to capture preys and avoid predation (Figure 2).

Mixotrophy, particularly phagotrophy, may have been a major contributor to the formation of harmful algal blooms and the achievement of a cosmopolitan distribution in species of Karlodinium, K. veneficum in particular, which thus deserves more in-depth investigations regarding the knowledge gaps that we have at least partly identified above. 


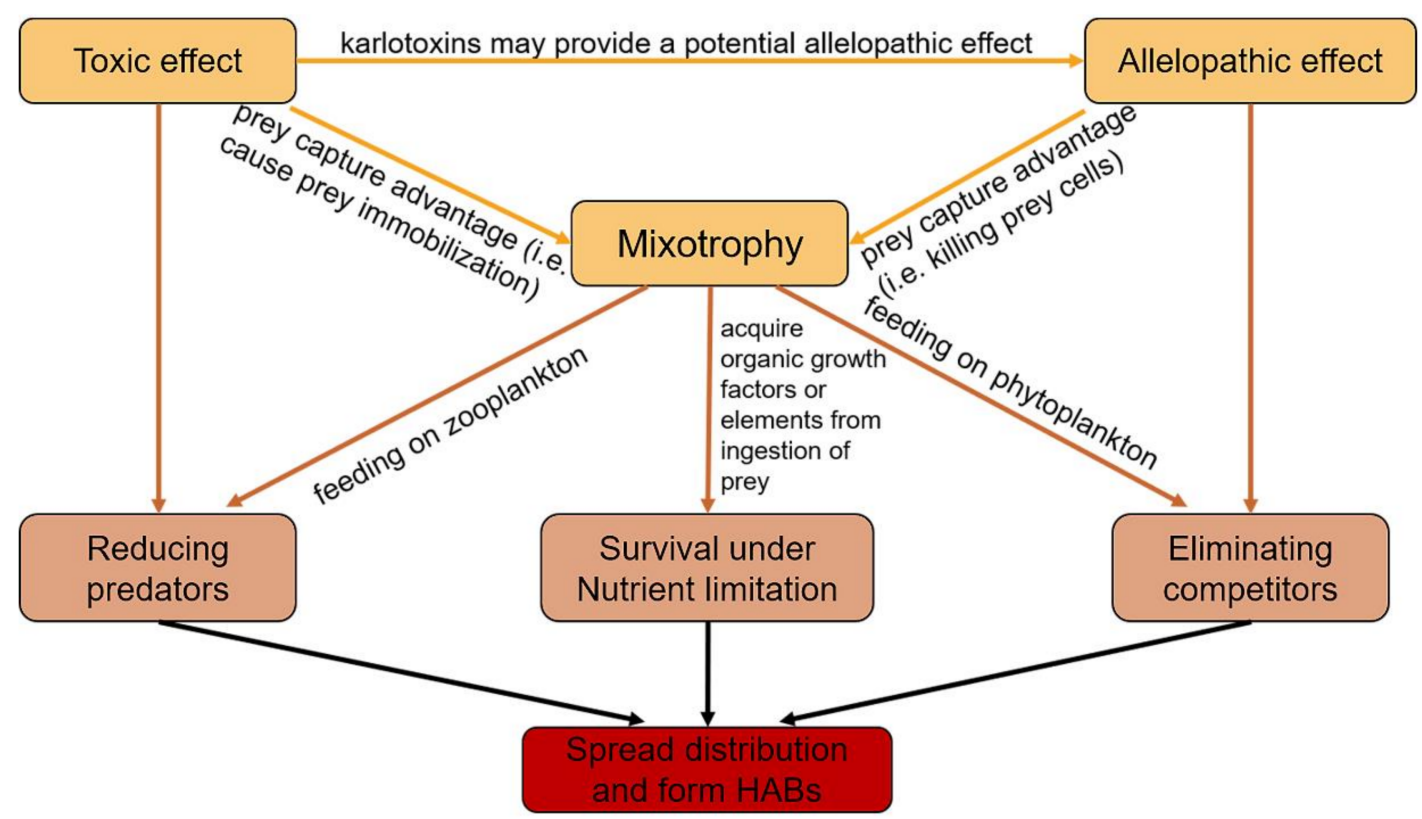

Figure 2. The relationship of phago-mixotrophy with toxicity and allelopathy of Karlodinium, and the implications for their global distribution and harmful algal blooms (HABs).

Author Contributions: Conceptualization, Y.Z.T.; literature search, H.Y., Z.H., and Y.Z.T.; validation, H.Y., Z.H., and Y.Z.T.; resources, Y.Z.T.; writing-original draft preparation, H.Y.; writing-review and editing, H.Y., Z.H., and Y.Z.T.; supervision, Y.Z.T.; funding acquisition, Y.Z.T. All authors have read and agreed to the published version of the manuscript.

Funding: This research was funded by the Key Deployment Project of Centre for Ocean MegaResearch of Science, Chinese Academy of Sciences, grant number COMS2019Q09, and the National Science Foundation of China, grant numbers 41776125, 41976134, and 61533011.

Institutional Review Board Statement: Not applicable.

Data Availability Statement: Data sharing not applicable.

Conflicts of Interest: The authors declare no conflict of interest. The funders had no role in the design of the study; in the collection, analyses, or interpretation of data; in the writing of the manuscript, or in the decision to publish the results.

\section{References}

1. Charles, B.M.; Patricia, A.W. Biological Oceanography, 2nd ed.; Wiley-Blackwell: Chichester, UK, 2012; pp. 1-464.

2. Long, S.P.; Humphries, S.; Falkowski, P.G. Photoinhibition of photosynthesis in nature. Annu. Rev. Plant Physiol. Plant Mol. Biol. 1994, 45, 633-662. [CrossRef]

3. Falkowski, P.G.; Barber, R.T.; Smetacek, V. Biogeochemical controls and feedbacks on ocean primary production. Science 1998, 281, 200-206. [CrossRef] [PubMed]

4. Burkholder, J.A.M.; Glibert, P.M.; Skelton, H.M. Mixotrophy, a major mode of nutrition for harmful algal species in eutrophic waters. Harmful Algae 2008, 8, 77-93. [CrossRef]

5. Gomez, F. A quantitative review of the lifestyle, habitat and trophic diversity of dinoflagellates (Dinoflagellata, Alveolata). Syst. Biodivers. 2012, 10, 267-275. [CrossRef]

6. $\quad$ Lin, S.; Cheng, S.; Song, B.; Zhong, X.; Lin, X.; Li, W.; Li, L.; Zhang, Y.; Zhang, H.; Ji, Z.; et al. The Symbiodinium kawagutii genome illuminates dinoflagellate gene expression and coral symbiosis. Science 2015, 350, 691-694. [CrossRef]

7. Smayda, T.J. Harmful algal blooms: Their ecophysiology and general relevance to phytoplankton blooms in the sea. Limnol. Oceanog. 1997, 42, 1137-1153. [CrossRef]

8. Cullen, J.J.; Yang, X.; Macintyre, H.L. Nutrient limitation of marine photosynthesis. In Primary Productivity and Biogeochemical Cycles in the Sea; Falkowski, P.G., Ed.; Plenum Press: New York, NY, USA, 1992; Volume 43, pp. 69-88.

9. Tang, E.P.Y. Why do dinoflagellates have lower growth rates? J. Phycol. 1996, 32, 80-84. [CrossRef]

10. Jones, R.I. Mixotrophy in Planktonic protists as a spectrum of nutritional strategies. Mar. Microbial Food Webs 1994, 8, 87-96.

11. Jones, R.I. Mixotrophy in planktonic protists: An overview. Freshw. Biol. 2000, 45, 219-226. [CrossRef] 
12. Hammer, A.C.; Pitchford, J.W. The role of mixotrophy in plankton bloom dynamics, and the consequences for productivity. ICES J. Mar. Sci. 2005, 62, 833-840. [CrossRef]

13. Gaines, G. Heterotrophic nutrition. Biology of Dinoflagellates. In The biology of dinoflagellates; Taylor, F.J.R., Ed.; Blackwell: Oxford, UK, 1987; pp. 224-267.

14. Skovgaard, A. Mixotrophy in Fragilidium subglobosum (Dinophyceae): Growth and grazing responses as functions of light intensity. Mar. Ecol. Prog. 1996, 143, 247-253. [CrossRef]

15. Daugbjerg, N.; Hansen, G.; Larsen, J.; Moestrup, O. Phylogeny of some of the major genera of dinoflagellates based on ultrastructure and partial LSU rDNA sequence data, including the erection of three new genera of unarmoured dinoflagellates. Phycologia 2000, 39, 302-317. [CrossRef]

16. Yang, H.; Hu, Z.; Shang, L.; Deng, Y.; Tang, Y.Z. A strain of the toxic dinoflagellate Karlodinium veneficum isolated from the East China Sea is an omnivorous phagotroph. Harmful Algae 2020, 93, 101775. [CrossRef] [PubMed]

17. Hallegraeff, G.; Mooney, B.; Evans, K.; Hosja, W. What Triggers Fish-Killing Karlodinium veneficum Dinoflagellate Blooms in the Swan Canning River System; Swan Canning Research and Innovation Program Final Report; Swan River Trust: Perth, Australia, $2010 ;$ p. 31.

18. Lim, H.C.; Leaw, C.P.; Tan, T.H.; Kon, N.F.; Yek, L.H.; Hii, K.S.; Teng, S.T.; Razali, R.M.; Usup, G.; Iwataki, M.; et al. A bloom of Karlodinium australe (Gymnodiniales, Dinophyceae) associated with mass mortality of cage-cultured fishes in West Johor Strait, Malaysia. Harmful Algae 2014, 40, 51-62. [CrossRef]

19. Adolf, J.E.; Bachvaroff, T.R.; Krupatkina, D.N.; Nonogaki, H.; Brown, P.J.P.; Lewitus, A.J.; Harvey, H.R.; Place, A.R. Species specificity and potential roles of Karlodinium micrum toxin. Afr. J. Mar. Sci. 2006, 28, 415-419. [CrossRef]

20. Li, A.S.; Stoecker, D.K.; Adolf, J.E. Feeding, pigmentation, photosynthesis and growth of the mixotrophic dinoflagellate Gyrodinium galatheanum. Aquat. Microb. Ecol. 1999, 19, 163-176. [CrossRef]

21. Li, A.S.; Stoecker, D.K.; Coats, D.W. Mixotrophy in Gyrodinium galatheanum (Dinophyceae): Grazing responses to light intensity and inorganic nutrients. J. Phycol. 2000, 36, 33-45. [CrossRef]

22. Li, A.S.; Stoecker, D.K.; Coats, D.W. Spatial and temporal aspects of Gyrodinium galatheanum in Chesapeake Bay: Distribution and mixotrophy. J. Plankton Res. 2000, 22, 2105-2124. [CrossRef]

23. Nielsen, M.V. Growth and chemical composition of the toxic dinoflagellate Gymnodinium galatheanum in relation to irradiance, temperature and salinity. Mar. Ecol. Prog. 1996, 136, 205-211. [CrossRef]

24. Delgado, M.; Alcaraz, M. Interactions between red tide microalgae and herbivorous zooplankton: The noxious effects of Gyrodinium corsicum (Dinophyceae) on Acartia grani (Copepoda: Calanoida). J. Plankton Res. 1999, 21, 2361-2371. [CrossRef]

25. Deeds, J.R.; Terlizzi, D.E.; Adolf, J.E.; Stoecker, D.K.; Place, A.R. Toxic activity from cultures of Karlodinium micrum (=Gyrodinium galatheanum) (Dinophyceae)—a dinoflagellate associated with fish mortalities in an estuarine aquaculture facility. Harmful Algae 2002, 1, 169-189. [CrossRef]

26. Fernández-Tejedor, M.; Soubrier-Pedreño, M.Á.; Ma, D.F. Acute LD of a Gyrodinium corsicum natural population for Sparus aurata and Dicentrarchus labrax. Harmful Algae 2004, 3, 1-9. [CrossRef]

27. Da Costa, M.R.; Franco, J.; Cacho, E.; Fernández, F. Toxin content and toxic effects of the dinoflagellate Gyrodinium corsicum (Paulmier) on the ingestion and survival rates of the copepods Acartia grani and Euterpina acutifrons. J. Exp. Mar. Biol. Ecol. 2005, 322, 177-183. [CrossRef]

28. de Salas, M.F.; Bolch, C.J.S.; Hallegraeff, G.M. Karlodinium australe sp. nov. (Gymnodiniales, Dinophyceae), a new potentially ichthyotoxic unarmoured dinoflagellate from lagoonal habitats of south-eastern Australia. Phycologia 2005, 44, 640-650. [CrossRef]

29. Garcés, E.; Fernandez, M.; Penna, A.; Lenning, K.V.; Gutierrez, A.; Camp, J.; Zapata, M. Characterization of NW Mediterranean Karlodinium spp. (Dinophyceae) strains using morphological, molecular, chemical, and physiological methodologies. J. Phycol. 2006, 42, 1096-1112. [CrossRef]

30. Adolf, J.E.; Bachvaroff, T.R.; Deeds, J.R.; Place, A.R. Ichthyotoxic Karlodinium veneficum (Ballantine) J Larsen in the upper Swan River estuary (Western Australia): Ecological conditions leading to a fish kill. Harmful Algae 2015, 48, 83-93. [CrossRef]

31. Van Wagoner, R.M.; Deeds, J.R.; Tatters, A.O.; Place, A.R.; Tomas, C.R.; Wright, J.L.C. Structure and relative potency of several karlotoxins from Karlodinium veneficum. J. Nat. Prod. 2010, 73, 1360-1365. [CrossRef]

32. Cai, P.; He, S.; Zhou, C.; Place, A.R.; Haq, S.; Ding, L.; Chen, H.; Jiang, Y.; Guo, C.; Xu, Y.; et al. Two new karlotoxins found in Karlodinium veneficum (strain GM2) from the East China Sea. Harmful Algae 2016, 58, 66-73. [CrossRef]

33. Krock, B.; Busch, J.A.; Tillmann, U.; Garcia-Camacho, F.; Sanchez-Miron, A.; Gallardo-Rodriguez, J.J.; Lopez-Rosales, L.; Andree, K.B.; Fernandez-Tejedor, M.; Witt, M.; et al. LC-MS/MS detection of karlotoxins reveals new variants in strains of the marine dinoflagellate Karlodinium veneficum from the Ebro Delta (NW Mediterranean). Mar. Drugs 2017, 15. [CrossRef]

34. Mooney, B.D.; de Salas, M.; Hallegraeff, G.M.; Place, A.R. Survey for karlotoxin production in 15 species of gymnodinioid dinoflagellates (Kareniaceae, Dinophyta). J. Phycol. 2009, 45, 164-175. [CrossRef]

35. Mooney, B.D.; Hallegraeff, G.M.; Place, A.R. Ichthyotoxicity of four species of gymnodinioid dinoflagellates (Kareniaceae, Dinophyta) and purified karlotoxins to larval sheepshead minnow. Harmful Algae 2010, 9, 557-562. [CrossRef]

36. Andersen, A.; De, L.M.; Binzer, S.B.; Rasmussen, S.A.; Hansen, P.J.; Nielsen, K.F.; Jørgensen, K.; Larsen, T.O. HPLC-HRMS quantification of the ichthyotoxin karmitoxin from Karlodinium armiger. Mar Drugs 2017, 15, 278. [CrossRef] [PubMed]

37. Rasmussen, S.A.; Binzer, S.B.; Hoeck, C.; Meier, S.; de Medeiros, L.S.; Andersen, N.G.; Place, A.; Nielsen, K.F.; Hansen, P.J.; Larsen, T.O. Karmitoxin: An amine-containing polyhydroxy-polyene toxin from the marine dinoflagellate Karlodinium armiger. J. Nat. Prod. 2017, 80, 1287-1293. [CrossRef] [PubMed] 
38. Bergholtz, T.; Daugbjerg, N.; Moestrup, Ø.; Fernández-Tejedor, M. On the identity of Karlodinium veneficum and description of Karlodinium armiger sp. nov. (Dinophyceae), based on light and electron microscopy, nuclear-encoded LSU rDNA, and pigment composition. J. Phycol. 2005, 42, 170-193. [CrossRef]

39. Toldrà, A.; Jauset-Rubio, M.; Andree, K.B.; Fernández-Tejedor, M.; Diogène, J.; Katakis, I.; O'Sullivan, C.K.; Campàs, M. Detection and quantification of the toxic marine microalgae Karlodinium veneficum and Karlodinium armiger using recombinase polymerase amplification and enzyme-linked oligonucleotide assay. Anal. Chim. Acta 2018, 1039, 140-148. [CrossRef] [PubMed]

40. Berge, T.; Hansen, P.J.; Moestrup, O. Prey size spectrum and bioenergetics of the mixotrophic dinoflagellate Karlodinium armiger. Aquat. Microb. Ecol. 2008, 50, 289-299. [CrossRef]

41. Berge, T.; Poulsen, L.K.; Moldrup, M.; Daugbjerg, N.; Hansen, P.J. Marine microalgae attack and feed on metazoans. Isme J. 2012, 6, 1926-1936. [CrossRef]

42. Leong, S.C.Y.; Lim, L.P.; Chew, S.M.; Kok, J.W.K.; Teo, S.L.M. Three new records of dinoflagellates in Singapore's coastal waters, with observations on environmental conditions associated with microalgal growth in the Johor Straits. Raffles Bull. Zool. 2015, 24-36.

43. De Salas, M.F.; Laza-Martínez, A.; Hallegraeff, G.M. Novel unarmored dinoflagellates from the toxigenic family Kareniaceae (Gymnodiniales): Five new species of Karlodinium and one new Takayama from the Australian sector of the southern ocean. J. Phycol. 2008, 44, 241-257. [CrossRef]

44. Benico, G.; Takahashi, K.; Lum, W.M.; Yniguez, A.T.; Iwataki, M. The harmful unarmored dinoflagellate Karlodiniumin Japan and Philippines, with reference to ultrastructure and micropredation of Karlodinium azanzae sp. nov. (Kareniaceae, Dinophyceae). J. Phycol. 2020, 56, 1264-1282. [CrossRef]

45. Escobar-Morales, S.; Hernandez-Becerril, D.U. Free-living marine planktonic unarmoured dinoflagellates from the Gulf of Mexico and the Mexican Pacific. Botanica Marina 2015, 58, 9-22. [CrossRef]

46. Zingone, A.; Siano, R.; D'Alelio, D.; Sarno, D. Potentially toxic and harmful microalgae from coastal waters of the Campania region (Tyrrhenian Sea, Mediterranean Sea). Harmful Algae 2006, 5, 321-337. [CrossRef]

47. Paulmier, G.; Berland, B.; Billard, C.; Nezan, E. Gyrodinium corsicum nov. sp. (Gymnodiniales, Dinophycean), responsible organism of the green water in salt-water lake of Diana (Corsica), in April 1994. Cryptogamie Algol. 1995, 16, 77-94.

48. Cen, J.; Wang, J.; Huang, L.; Ding, G.; Qi, Y.; Cao, R.; Cui, L.; Lv, S. Who is the"murderer"of the bloom in coastal waters of Fujian, China, in 2019? J. Oceanol. Limnol. 2020, 38, 722-732. [CrossRef]

49. Yang, Z.B.; Takayama, H.; Matsuoka, K.; Hodgkiss, I.J. Karenia digitata sp. nov. (Gymnodiniales, Dinophyceae), a new harmful algal bloom species from the coastal waters of west Japan and Hong Kong. Phycologia 2000, 39, 463-470. [CrossRef]

50. Cen, J.; Wang, J.; Huang, L.; Lin, Y.; Ding, G.; Qi, Y.; Lv, S. Karlodinium elegans sp. nov. (Gymnodiniales, Dinophyceae), a novel species isolated from the East China Sea in a dinoflagellate bloom. J. Oceanol. Limnol. 2020, 1-17. [CrossRef]

51. Nezan, E.; Siano, R.; Boulben, S.; Six, C.; Bilien, G.; Cheze, K.; Duval, A.; Le Panse, S.; Quere, J.; Chomerat, N. Genetic diversity of the harmful family Kareniaceae (Gymnodiniales, Dinophyceae) in France, with the description of Karlodinium gentienii sp. nov.: A new potentially toxic dinoflagellate. Harmful Algae 2014, 40, 75-91. [CrossRef]

52. Ballantine, D. Two new marine species of Gymnodinium isolated from the Plymouth area. J. Mar. Biol. Assoc. UK 1956, 35, 467-474. [CrossRef]

53. Hallett, C.S.; Valesini, F.J.; Clarke, K.R.; Hoeksema, S.D. Effects of a harmful algal bloom on the community ecology, movements and spatial distributions of fishes in a microtidal estuary. Hydrobiologia 2016, 763, 267-284. [CrossRef]

54. Granéli, E.; Turner, J.T. Ecology of Harmful Algae; Springer: Berlin/Heidelberg, Germany, 2006; pp. 1-413.

55. Zhu, X.; Zhou, C.; Meng, R.; Li, S.; Fang, K.; Luo, Z.; Xu, J.; He, S.; Luo, Q.; Yan, X. Biochemical characteristics support the recently described species Karlodinium zhouanum (Gymnodiniales, Dinophyceae). Phycol. Res. 2019, 68, 14-22. [CrossRef]

56. Luo, Z.; Wang, L.; Chan, L.; Lu, S.; Gu, H. Karlodinium zhouanum, a new dinoflagellate species from China, and molecular phylogeny of Karenia digitata and Karenia longicanalis (Gymnodiniales, Dinophyceae). Phycologia 2018, 57, 401-412. [CrossRef]

57. Li, Z.; Shin, H.H. Morphology and phylogeny of an unarmored dinoflagellate, Karlodinium jejuense sp. nov. (Gymnodiniales), isolated from the northern East China Sea. Phycol. Res. 2018, 66, 318-328. [CrossRef]

58. Sheng, J.; Malkiel, E.; Katz, J.; Adolf, J.E.; Place, A.R. A dinoflagellate exploits toxins to immobilize prey prior to ingestion. Proc. Natl Acad. Sci. USA 2010, 107, 2082-2087. [CrossRef] [PubMed]

59. Berge, T.; Hansen, P.J.; Moestrup, O. Feeding mechanism, prey specificity and growth in light and dark of the plastidic dinoflagellate Karlodinium armiger. Aquat. Microb. Ecol. 2008, 50, 279-288. [CrossRef]

60. Stoecker, D.K. Mixotrophy among dinoflagellates. J. Eukaryot. Microbiol. 1999, 46, 397-401. [CrossRef]

61. Schnepf, E.; Elbrächter, M. Nutritional strategies in dinoflagellates: A review with emphasis on cell biological aspects. Eur. J. Protistol. 1992, 28, 3-24. [CrossRef]

62. Biecheler, B. Recherches sur les Péridiniens. Bull. Biol. Fr. Belg. 1952, 36, 1-149.

63. Calado, A.J.; Moestrup, $\varnothing$. Feeding in Peridiniopsis berolinensis (Dinophyceae): New observations on tube feeding by an omnivorous, heterotrophic dinoflagellate. Phycologia 1997, 36, 47-59. [CrossRef]

64. Hansen, P.J.; Calado, A.J. Phagotrophic mechanisms and prey selection in free-living dinoflagellates. J. Eukaryot. Microbiol. 1999, 46, 382-389. [CrossRef]

65. Jacobson, D.M.; Anderson, D.M. Thecate heterophic dinoflagellates: Feeding behavior and mechanisms. J. Phycol. 1986, 22, 249-258. [CrossRef] 
66. Jeong, H.J.; Latz, M.I. Growth and grazing rates of the heterotrophic dinoflagellates Protoperidinium spp. on red tide dinoflagellates. Mar. Ecol. Prog. Ser. 1994, 106, 173-185. [CrossRef]

67. Elbrächter, M. Food uptake mechanisms in phagotrophic dinoflagellates and classification. In The Biology of Free-Living Heterotrophic Flagellates; Patterson, D.J., Larsen, J., Eds.; Clarendon Press: Oxford, UK, 1991; Volume 45, pp. $303-312$.

68. Schnepf, E.; Deichgräber, G. "Myzocytosis", a kind of endocytosis with implications to compartmentation in endosymbiosis. Naturwissenschaften 1984, 71, 218-219. [CrossRef]

69. Spero, H.J. Phagotrophy in Gymnodinium fungiforme (Pyrrhophyta): The peduncle as an organelle of ingestion. J. Phycol. 1982, 18, 356-360. [CrossRef]

70. Wilcox, L.W.; Wedemayer, G.J. Phagotrophy in the freshwater, photosynthetic dinoflagellate Amphidinium cryophilum. J. Phycol. 1991, 27, 600-609. [CrossRef]

71. Schnepf, E.; Deichgräber, G.; Drebes, G. Food uptake and the fine structure of the dinophyte Paulsenella sp., an ectoparasite of marine diatoms. Protoplasma 1985, 124, 188-204. [CrossRef]

72. Place, A.R.; Bowers, H.A.; Bachvaroff, T.R.; Adolf, J.E.; Deeds, J.R.; Sheng, J. Karlodinium veneficum -The little dinoflagellate with a big bite. Harmful Algae 2012, 14, 179-195. [CrossRef]

73. Song, X.; Hu, Z.; Shang, L.; Leaw, C.P.; Lim, P.T.; Tang, Y.Z. Contact micropredation may play a more important role than exotoxicity does in the lethal effects of Karlodinium australe blooms: Evidence from laboratory bioassays. Harmful Algae 2020, 99, 101926. [CrossRef]

74. Vogelbein, W.K.; Lovko, V.J.; Shields, J.D.; Reece, K.S.; Mason, P.L.; Haas, L.W.; Walker, C.C. Pfiesteria shumwayae kills fish by micropredation not exotoxin secretion. Nature 2002, 418, 967-970. [CrossRef]

75. Lafferty, K.D.; Kuris, A.M. Trophic strategies, animal diversity and body size. Trends Ecol. Evol. 2002, 17, 507-513. [CrossRef]

76. Spero, H.J. Chemosensory capabilities in the phagotrophic dinoflagellate Gymnodinium fungiforme. J. Phycol. 1985, 21, 181-184. [CrossRef]

77. Sheng, J.; Malkiel, E.; Katz, J.; Adolf, J.; Belas, R.; Place, A.R. Digital holographic microscopy reveals prey-induced changes in swimming behavior of predatory dinoflagellates. Proc. Natl Acad. Sci. USA 2007, 104, 17512-17517. [CrossRef] [PubMed]

78. Hansen, P.J. Prey size selection, feeding rates and growth dynamics of heterotrophic dinoflagellates with special emphasis on Gyrodinium-spirale. Mar. Biol. 1992, 114, 327-334. [CrossRef]

79. Schnepf, E.; Winter, S.; Mollenhauer, D. Gymnodinium aeruginosum (Dinophyta): A blue-green dinoflagellate with a vestigial, anucleate, cryptophycean endosymbiont. Plant Syst. Evol. 1989, 164, 75-91. [CrossRef]

80. Skovgaard, A. Role of chloroplast retention in a marine dinoflagellate. Aquat. Microb. Ecol. 1998, 15, 293-301. [CrossRef]

81. Wilcox, L.W.; Wedemayer, G.J. Gymnodinium acidotum Nygaard (Pyrrophyta), a dinoflagellate with an endosymbiotic cryptomonad. J. Phycol. 2010, 20, 236-242. [CrossRef]

82. Hansen, P.J. Phagotrophic mechanisms and prey selection in mixotrophic phytoflagellates. Physiol. Ecol. Harmful Algal Blooms 1998, 525-537.

83. Jakobsen, H.H.; Hansen, P.J.; Larsen, J. Growth and grazing responses of two chloroplast-retaining dinoflagellates: Effect of irradiance and prey species. Mar. Ecol. Prog. Ser. 2000, 201, 121-128. [CrossRef]

84. Hansen, P.J. The role of photosynthesis and food uptake for the growth of marine mixotrophic dinoflagellates. J. Eukaryot. Microbiol. 2011, 58, 203-214. [CrossRef]

85. Adolf, J.E.; Stoecker, D.K.; Harding, L.W., Jr. The balance of autotrophy and heterotrophy during mixotrophic growth of Karlodinium micrum (Dinophyceae). J. Plankton Res. 2006, 28, 737-751. [CrossRef]

86. Adolf, J.E.; Bachvaroff, T.; Place, A.R. Can cryptophyte abundance trigger toxic Karlodinium veneficum blooms in eutrophic estuaries? Harmful Algae 2008, 8, 119-128. [CrossRef]

87. Bachvaroff, T.R.; Adolf, J.E.; Place, A.R. Strain variation in Karlodinium veneficum (Dinophyceae): Toxin profiles, pigments, and growth characteristics. J. Phycol. 2009, 45, 137-153. [CrossRef] [PubMed]

88. Yang, H.; Hu, Z.; Xu, N.; Tang, Y.Z. A comparative study on the allelopathy and toxicity of four strains of Karlodinium veneficum with different culturing histories. J. Plankton Res. 2019, 41, 17-29. [CrossRef]

89. Stoecker, D.K.; Gustafson, D.E. Cell-surface proteolytic activity of photosynthetic dinoflagellates. Aquat. Microb. Ecol. 2003, 30, 175-183. [CrossRef]

90. Solomon, C.M.; Glibert, P.M. Urease activity in five phytoplankton species. Aquat. Microb. Ecol. 2008, 52, 149-157. [CrossRef]

91. Croft, M.T.; Warren, M.J.; Smith, A.G. Algae need their vitamins. Eukaryot. Cell 2006, 5, 1175-1183. [CrossRef]

92. Hellebust, J.A. Excretion of some organic compounds by marine phytoplankton. Limnol. Oceanogr. 1965, 10, 192-206. [CrossRef]

93. Kamjunke, N.; Tittel, J. Utilisation of leucine by several phytoplankton species. Limnologica 2008, 38, 360-366. [CrossRef]

94. Tittel, J.; Wiehle, I.; Wannicke, N.; Kampe, H.; Poerschmann, J.; Meier, J.; Kamjunke, N. Utilisation of terrestrial carbon by osmotrophic algae. Aquat. Sci. 2009, 71, 46-54. [CrossRef]

95. Beamud, S.G.; Karrasch, B.; Pedrozo, F.L.; Diaz, M.M. Utilisation of organic compounds by osmotrophic algae in an acidic lake of Patagonia (Argentina). Limnology 2014, 15, 163-172. [CrossRef]

96. Dabrowska, A.; Nawrocki, J.; Szelag-Wasielewska, E. Appearance of aldehydes in the surface layer of lake waters. Environ. Monit. Assess. 2014, 186, 4569-4580. [CrossRef]

97. Nygaard, K.; Tobiesen, A. Bacterivory in algae-A survival strategy during nutrient limitation. Limnol. Oceanogr. 1993, 38, 273-279. [CrossRef] 
98. Li, A.S.; Stoecker, D.K.; Coats, D.W.; Adam, E.J. Ingestion of fluorescently labeled and phycoerythrin-containing prey by mixotrophic dinoflagellates. Aquat. Microb. Ecol. 1996, 10, 139-147. [CrossRef]

99. Adolf, J.E.; Stoecker, D.K.; Harding, L.W. Autotrophic growth and photoacclimation in Karlodinium micrum (Dinophyceae) and Storeatula major (Cryptophyceae). J. Phycol. 2003, 39, 1101-1108. [CrossRef]

100. Li, J.; Glibert, P.M.; Alexander, J.A.; Molina, M.E. Growth and competition of several harmful dinoflagellates under different nutrient and light conditions. Harmful Algae 2012, 13, 112-125. [CrossRef]

101. Claessen, D.; de Roos, A.M.; Persson, L. Population dynamic theory of size-dependent cannibalism. Proc. R. Soc. Lond. Ser. B Biol. Sci. 2004, 271, 333-340. [CrossRef] [PubMed]

102. Martel, C.M.; Flynn, K.J. Morphological controls on cannibalism in a planktonic marine phagotroph. Protist 2008, $159,41-51$. [CrossRef]

103. Spero, H.J.; Moree, M.D. Phagotrophic feeding and its importance to the life cycle of the holozoic dinoflagellate, Gymnodinium fungiforme. J. Phycol. 1981, 17, 43-51. [CrossRef]

104. Schnepf, E.; Drebes, G. Chemotaxis and appetence of Paulsenella sp. (Dinophyta), an ectoparasite of the marine diatom Streptotheca thamesis Shrubsole. Planta 1986, 167, 337-343. [CrossRef]

105. Feinstein, T.N.; Traslavina, R.; Sun, M.Y.; Lin, S.J. Effects of light on photosynthesis, grazing, and population dynamics of the heterotrophic dinoflagellate Pfiesteria piscicida (Dinophyceae). J. Phycol. 2002, 38, 659-669. [CrossRef]

106. Jeong, H.J.; Lee, C.W.; Yih, W.H.; Kim, J.S. Fragilidium cf mexicanum, a thecate mixotrophic dinoflagellate which is prey for and a predator on co-occurring thecate heterotrophic dinoflagellate Protoperidinium cf. divergens. Mar. Ecol. Prog. Ser. 1997, 151, 299-305.

107. Naustvoll, L.J. Growth and grazing by the thecate heterotrophic dinoflagellate Diplopsalis lemicula (Diplopsalidaceae, Dinophyceae). Phycologia 1998, 37, 1-9. [CrossRef]

108. Margulis, L. Origins of Sex; Yale University Press: New Haven, CT, USA, 1986.

109. Raven, J.A.; Beardall, J.; Flynn, K.J.; Maberly, S.C. Phagotrophy in the origins of photosynthesis in eukaryotes and as a complementary mode of nutrition in phototrophs: Relation to Darwin's insectivorous plants. J. Exp. Bot. 2009, 60, 3975-3987. [CrossRef] [PubMed]

110. Leles, S.G.; Mitra, A.; Flynn, K.J.; Stoecker, D.K.; Hansen, P.J.; Calbet, A.; McManus, G.B.; Sanders, R.W.; Caron, D.A.; Not, F.; et al. Oceanic protists with different forms of acquired phototrophy display contrasting biogeographies and abundance. Proc. R. Soc. Lond. Ser. B Biol. Sci. 2017, 284, 20170664. [CrossRef]

111. Margulis, L.; Schwartz, K.V. Five Kingdoms; Freeman, W.H. and Company: San Francisco, CA, USA, 1982; pp. 1-338.

112. Porter, K.G. Phagotrophic phytoflagellates in microbial food webs. Hydrobiologia 1988, 159, 89-97. [CrossRef]

113. Stoecker, D.K.; Tillmann, U.; Granéli, E. Phagotrophy in harmful algae. In Ecology of Harmful Algae; Granéli, E., Turner, J.T., Eds.; Springer: Berlin, Germany, 2006; pp. 177-188.

114. Mitra, A.; Flynn, K.J.; Tillmann, U.; Raven, J.A.; Caron, D.; Stoecker, D.K.; Not, F.; Hansen, P.J.; Hallegraeff, G.; Sanders, R.; et al. Defining planktonic protist functional groups on mechanisms for energy and nutrient acquisition: Incorporation of diverse mixotrophic strategies. Protist 2016, 167, 106-120. [CrossRef] [PubMed]

115. Stoecker, D.K.; Hansen, P.J.; Caron, D.A.; Mitra, A.; Annual, R. Mixotrophy in the marine plankton. Ann. Rev. Mar. Sci. 2017, 9 , 311-335. [CrossRef] [PubMed]

116. Mitra, A.; Flynn, K.J.; Burkholder, J.M.; Berge, T.; Calbet, A.; Raven, J.A.; Graneli, E.; Glibert, P.M.; Hansen, P.J.; Stoecker, D.K.; et al. The role of mixotrophic protists in the biological carbon pump. Biogeosciences 2014, 11, 995-1005. [CrossRef]

117. Flynn, K.J.; Mitra, A.; Anestis, K.; Anschütz, A.A.; Calbet, A.; Ferreira, G.D.; Gypens, N.; Hansen, P.J.; John, U.; Martin, J.L.; et al. Mixotrophic protists and a new paradigm for marine ecology: Where does plankton research go now? J. Plankton Res. 2019, 4, 375-391. [CrossRef]

118. Legrand, C.; Granéli, E.; Carlsson, P. Induced phagotrophy in the photosynthetic dinoflagellate Heterocapsa triquetra. Aquat. Microb. Ecol. 1998, 15, 65-75. [CrossRef]

119. Berge, T.; Hansen, P.J. Role of the chloroplast in the predatory dinoflagellate Karlodinium armiger. Mar. Ecol. Prog. 2016, 519, 41-54. [CrossRef]

120. Naik, R.K.; Chitari, R.R.; Anil, A.C. Karlodinium veneficum in India: Effect of fixatives on morphology and allelopathy in relation to Skeletonema costatum. Curr. Sci. India. 2010, 99, 1112-1116.

121. Tittel, J.; Bissinger, V.; Zippel, B.; Gaedke, U.; Bell, E.; Lorke, A.; Kamjunke, N. Mixotrophs combine resource use to outcompete specialists: Implications for aquatic food webs. Proc. Natl Acad. Sci. USA 2003, 100, 12776-12781. [CrossRef] [PubMed]

122. Granéli, E.; Edvardsen, B.; Roelke, D.L.; Hagström, J.A. The ecophysiology and bloom dynamics of Prymnesium spp. Harmful Algae 2012, 14, 260-270. [CrossRef]

123. Cabrerizo, M.J.; Manuel Gonzalez-Olalla, J.; Hinojosa-Lopez, V.J.; Peralta-Cornejo, F.J.; Carrillo, P. A shifting balance: Responses of mixotrophic marine algae to cooling and warming under UVR. N. Phytol. 2019, 221, 1317-1327. [CrossRef]

124. Okada, M.; Huston, C.D.; Mann, B.J.; Petri, W.A.; Kita, K.; Nozaki, T. Proteomic analysis of phagocytosis in the enteric protozoan parasite Entamoeba histolytica. Eukaryot.Cell 2005, 4, 827-831. [CrossRef]

125. Gotthardt, D.; Blancheteau, V.; Bosserhoff, A.; Ruppert, T.; Delorenzi, M.; Soldati, T. Proteomics fingerprinting of phagosome maturation and evidence for the role of a G alpha during uptake. Mol. Cell. Proteomics 2006, 5, 2228-2243. [CrossRef]

126. Jacobs, M.E.; DeSouza, L.V.; Samaranayake, H.; Pearlman, R.E.; Siu, K.W.M.; Klobutcher, L.A. The Tetrahymena thermophila phagosome proteome. Eukaryot. Cell 2006, 5, 1990-2000. [CrossRef] 
127. Shevchuk, O.; Batzilla, C.; Haegele, S.; Kusch, H.; Engelmann, S.; Hecker, M.; Haas, A.; Heuner, K.; Gloeckner, G.; Steinert, M. Proteomic analysis of Legionella-containing phagosomes isolated from Dicyostelium. Int. J. Med. Microbiol. 2009, 299, 489-508. [CrossRef]

128. Boulais, J.; Trost, M.; Landry, C.R.; Dieckmann, R.; Levy, E.D.; Soldati, T.; Michnick, S.W.; Thibault, P.; Desjardins, M. Molecular characterization of the evolution of phagosomes. Mol. Syst. Biol. 2010, 6, 423. [CrossRef]

129. Burns, J.A.; Paasch, A.; Narechania, A.; Kim, E. Comparative genomics of a bacterivorous green alga reveals evolutionary causalities and consequences of phago-mixotrophic mode of nutrition. Genome Biol. Evol. 2015, 7, 3047-3061. [CrossRef]

130. Lie, A.A.Y.; Liu, Z.; Terrado, R.; Tatters, A.O.; Heidelberg, K.B.; Caron, D.A. Effect of light and prey availability on gene expression of the mixotrophic chrysophyte, Ochromonas sp. BMC Genomics 2017, 18, 163. [CrossRef] [PubMed] 